Louisiana State University

LSU Digital Commons

Faculty Publications

Department of Oceanography \& Coastal

Sciences

2016

\title{
Morphology, Molecular Phylogeny And Azaspiracid Profile Of Azadinium Poporum (Dinophyceae) From The Gulf Of Mexico
}

Zhaohe Luo

Bernd Krock

Bernd.Krock@awi.de

Kenneth Neil Mertens

Andrea Michelle Price

R. Eugene Turner

euturne@lsu.edu

See next page for additional authors

Follow this and additional works at: https://digitalcommons.Isu.edu/oceanography_coastal_pubs

\section{Recommended Citation}

Luo, Z., Krock, B., Mertens, K. N., Price, A. M., Turner, R., Rabalais, N. N., \& Gu, H. (2016). Morphology, Molecular Phylogeny And Azaspiracid Profile Of Azadinium Poporum (Dinophyceae) From The Gulf Of Mexico. Harmful Algae, 55, 56-65. https://doi.org/10.1016/j.hal.2016.02.006

This Article is brought to you for free and open access by the Department of Oceanography \& Coastal Sciences at LSU Digital Commons. It has been accepted for inclusion in Faculty Publications by an authorized administrator of LSU Digital Commons. For more information, please contact ir@lsu.edu. 


\section{Authors}

Zhaohe Luo, Bernd Krock, Kenneth Neil Mertens, Andrea Michelle Price, R. Eugene Turner, Nancy N. Rabalais, and Haifeng Gu 


\section{Review}

\section{Morphology, molecular phylogeny and azaspiracid profile of Azadinium poporum (Dinophyceae) from the Gulf of Mexico}

\section{Zhaohe Luo ${ }^{\mathrm{a}, \mathrm{b}}$, Bernd Krock ${ }^{\mathrm{c}, *}$, Kenneth Neil Mertens ${ }^{\mathrm{d}, 1}$, Andrea Michelle Price ${ }^{\mathrm{e}}$, Robert Eugene Turner ${ }^{\mathrm{f}}$, Nancy N. Rabalais ${ }^{\mathrm{g}}$, Haifeng Gu ${ }^{\mathrm{b}, *}$}

a College of Life Science and Technology, Jinan University, Guangzhou 510632, China

${ }^{\mathrm{b}}$ Third Institute of Oceanography, SOA, Xiamen 361005, China

${ }^{c}$ Alfred Wegener Institute for Polar and Marine Research, Am Handelshafen 12, D-27570 Bremerhaven, Germany

${ }^{\mathrm{d}}$ Research Unit for Palaeontology, Ghent University, Krijgslaan 281 S8, 9000 Ghent, Belgium

e Department of Geography, McGill University, Burnside Hall, 805 Sherbrooke Street West, Montreal, QC, Canada H3A OB9

${ }^{\mathrm{f}}$ Department of Oceanography and Coastal Sciences, Louisiana State University, Baton Rouge, LA 70803, USA

${ }^{g}$ Louisiana Universities Marine Consortium, Chauvin, LA 70344, USA

\section{A R T I C L E I N F O}

\section{Article history:}

Received 1 September 2015

Received in revised form 9 February 2016

Accepted 9 February 2016

Available online

\section{Keywords:}

AZA-2

AZA-2 phosphate

Biogeography

LC-MS/MS

LSU rDNA

Ribotype D

\begin{abstract}
A B S T R A C T
Azadinium poporum produces a variety of azaspiracids and consists of several ribotypes, but information on its biogeography is limited. A strain of $A$. poporum (GM29) was incubated from a Gulf of Mexico sediment sample. Strain GM29 was characterized by a plate pattern of po, cp, x, 4', 3a, 6", 6C, 5S, 6"', 2' ${ }^{\prime \prime \prime \prime}$, a distinct ventral pore at the junction of po and the first two apical plates, and a lack of an antapical spine, thus fitting the original description of A. poporum. The genus Azadinium has not been reported in waters of the United States of America before this study. Molecular phylogeny, based on large subunit ribosomal DNA (LSU rDNA) and internal transcribed spacer (ITS) sequences, reveals that strain GM29 is nested within the well-resolved $A$. poporum complex, but forms a sister clade either to ribotype B (ITS) or ribotype C (LSU). It is, therefore, designated as a new ribotype, termed as ribotype D. LSU and ITS sequences similarity among different ribotypes of $A$. poporum ranges from $95.4 \%$ to $98.2 \%$, and from $97.1 \%$ to $99.2 \%$ respectively, suggesting that the LSU fragment is a better candidate for molecular discrimination. Azaspiracid profiles were analyzed using LC-MS/MS and demonstrate that strain GM29 produces predominantly AZA-2 with an amount of $45 \mathrm{fg} /$ cell. The results suggest that $A$. poporum has a wide distribution and highlights the risk potential of azaspiracid intoxication in the United States.
\end{abstract}

(c) 2016 Elsevier B.V. All rights reserved.

\section{Contents}

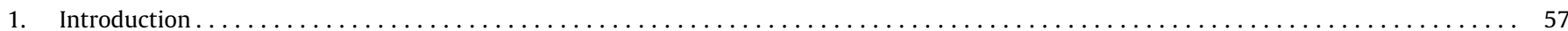

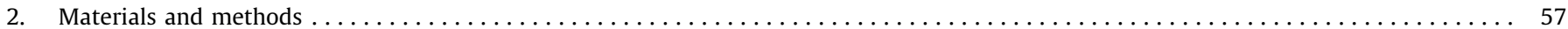

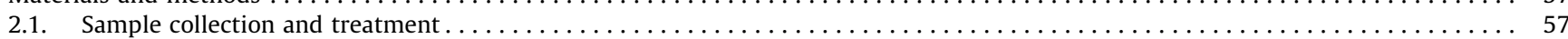

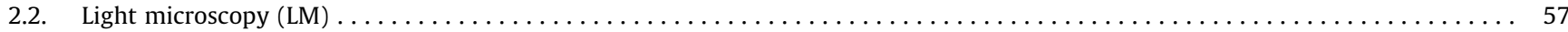

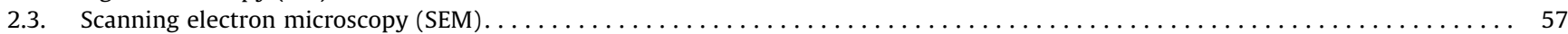

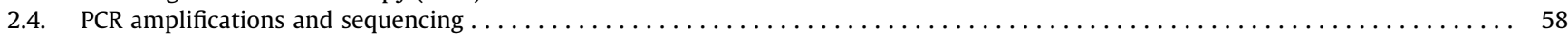

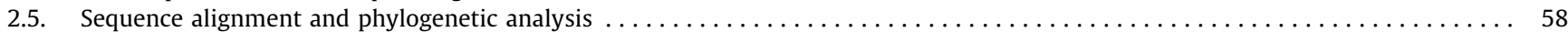

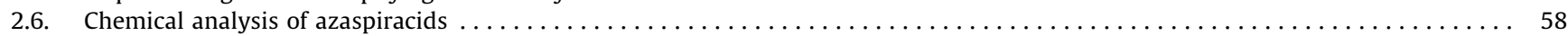

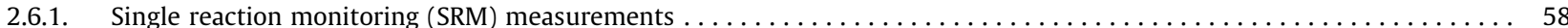

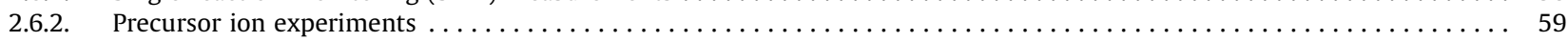

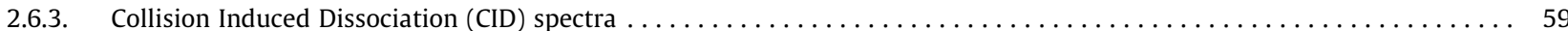

\footnotetext{
* Corresponding authors.

E-mail addresses: bernd.krock@awi.de (B. Krock), guhaifeng@tio.org.cn (H. Gu).

${ }^{1}$ Now at: Ifremer, LER BO, Station de Biologie Marine, Place de la Croix, BP40537, F-29185 Concarneau Cedex, France.
} 


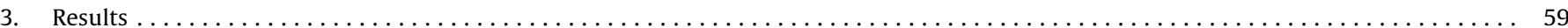

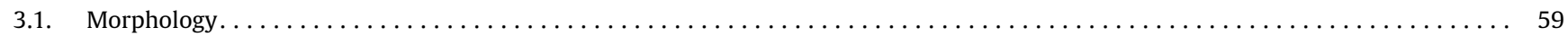

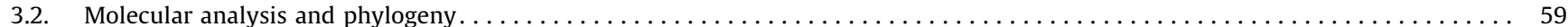

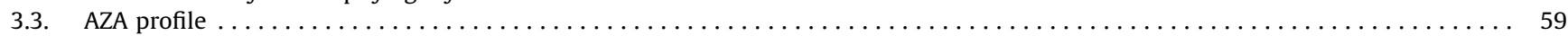

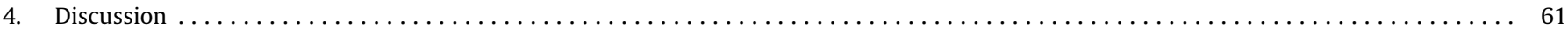

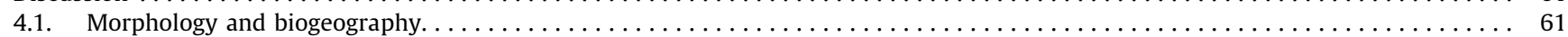

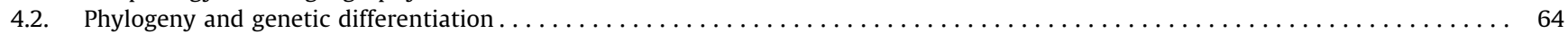

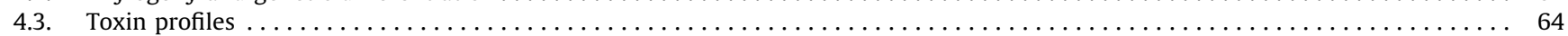

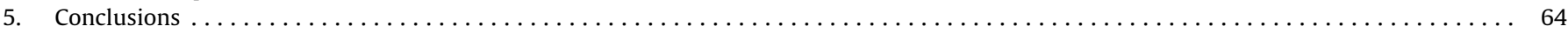

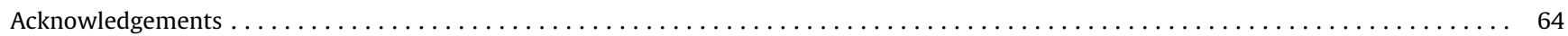

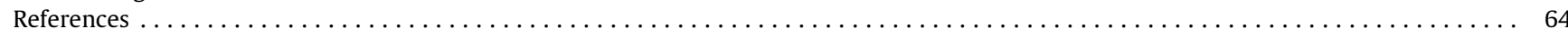

\section{Introduction}

The known diversity of the dinophyte genus Azadinium Elbrächter and Tillmann has increased rapidly. Up to ten species have been described in the past five years (Tillmann et al., 2009, 2010, 2011, 2014; Luo et al., 2013; Percopo et al., 2013). Additionally, Amphidoma caudata Halldal has been transferred to Azadinium based on both morphology and molecular phylogeny (Nézan et al., 2012). The genus Azadinium was characterized by a plate pattern of po, cp, x, 3-4', 2-3a, 6", 6C, 5S, 6"', $2^{\prime \prime \prime \prime}$ (Tillmann et al., 2009; Luo et al., 2013), in which the presence of anterior intercalary plates and a canal plate resembles the Peridiniales and the presence of six precingular and postcingular plates resembles the Gonyaulacales. In the molecular phylogeny, the genus Azadinium is monophyletic and forms an independent lineage together with Amphidoma Stein, which is classified within the family Amphidomataceae, but its higher level designation remains to be determined (Tillmann et al., 2012a, 2014).

Most Azadinium species were described from samples collected in European waters, but that does not mean that there is a restricted distribution of these small dinoflagellates. For example, Azadinium spinosum was also reported in the Mexican Pacific (Hernández-Becerril et al., 2012), and Azadinium poporum was found in Korea (Potvin et al., 2011), China (Gu et al., 2013), New Zealand (Smith et al., 2015) and Argentina (Tillmann et al., 2016). Azadinium diversity might be underestimated because their cells are rather small and molecular detection is not routinely carried out (Toebe et al., 2013).

The type species of Azadinium (A. spinosum) was related to azaspiracids (AZA-1 and AZA-2) and thus was the organism responsible for cases of human intoxication via mussel consumption (Tillmann et al., 2009). Later, two other species (Azadinium dexteroporum, Azadinium poporum) were found to contain AZAs too (Percopo et al., 2013; Gu et al., 2013; Krock et al., 2014). It is worth noting that $A$. poporum comprises several genetically different ribotypes that are morphologically identical. The strains from Europe and New Zealand share identical sequences and belong to ribotype A, whereas those from Korea, China and Argentina belong to ribotype B or C (Gu et al., 2013; Smith et al., 2015; Tillmann et al., 2016). Additional ribotypes can be expected to be discovered because only a limited number of $A$. poporum strains have been sequenced.

The presence of azaspiracids (AZA) has been reported in mussels of northern Africa (Taleb et al., 2006), mussels from northern Europe (Satake et al., 1998), scallops and mussels from Chile (Lopez-Rivera et al., 2010), a marine sponge from Japan (Ueoka et al., 2009), shellfish from China (Yao et al., 2010), shellfish from New Zealand (Smith et al., 2015) and plankton samples from the Pacific coast of the USA (Trainer et al., 2013). However, AZA producing species have not been reported in some of these areas, e.g., from the USA. Incubated sediment samples from the northern Gulf of Mexico, generated one strain of Azadinium poporum. Its morphology was examined in detail, and its partial large subunit ribosomal DNA (LSU rDNA) and internal transcribed spacer regions (ITS) sequences were determined. This strain was also grown in larger quantities and analyzed for the presence of AZAs.

\section{Materials and methods}

\subsection{Sample collection and treatment}

A box core was collected from the northern Gulf of Mexico (29.3250 $\mathrm{N}, 93.4167^{\circ} \mathrm{W}$, water depth: $17.3 \mathrm{~m}$ ) on August 1, 2014. The top $2 \mathrm{~cm}$ were sliced off and stored in the dark at $4{ }^{\circ} \mathrm{C}$ until further treatment. Approximately $5 \mathrm{~g}$ of wet sediment was mixed with $20 \mathrm{~mL}$ of filtered sea water and sonicated for $2 \mathrm{~min}(100 \mathrm{~W})$ to dislodge detrital particles. The watery slurry was incubated directly in a series of small containers in f/2-Si medium (Guillard and Ryther, 1962) at $20^{\circ} \mathrm{C}, 90 \mu \mathrm{E} \mathrm{m}^{-2} \mathrm{~s}^{-1}$ under a $12: 12 \mathrm{~h}$ light:dark cycle (hereafter called "standard culture conditions"). Azadinium cells are characterized by swimming at low speed, interrupted by short, high-speed 'jumps' in various directions (Tillmann et al., 2009). Cells exhibiting such a characteristic swimming behavior were isolated by means of drawn-out Pasteur pipettes and established in clonal cultures. Only one strain (GM29) was established from one container, and it was maintained under standard culture conditions.

\subsection{Light microscopy (LM)}

Live cells were examined under a Zeiss Axio Imager microscope (Carl Zeiss, Göttingen, Germany) equipped with both differential interference illumination and epifluorescence. Light micrographs were obtained using a Zeiss AxiocamHRc digital camera. Approximately $1 \mathrm{~mL}$ of live, healthy culture in mid exponential growth phase was transferred to a $1.5 \mathrm{~mL}$ microcentrifuge tube, and stained with 1:100,000 Sybr Green (Sigma-Aldrich, St. Louis, USA) for $10 \mathrm{~min}$. The cells were viewed and photographed through a Zeiss Filterset (excitation BP 450-490; beamsplitter FT 510; emission LP 515). Cells in mid-exponential growth phase were fixed with 5\% Lugol's solution and cell sizes were measured at $400 \times$ magnification. Thirty cells were measured for the strain GM29.

\subsection{Scanning electron microscopy (SEM)}

Mid-exponential batch cultures were collected by centrifugation at $5000 \mathrm{rpm}$ to use for scanning electron microscopy (SEM). The supernatant was removed and the cell pellet that was resuspended in $60 \%$ ethanol for $1 \mathrm{~h}$ at $8{ }^{\circ} \mathrm{C}$ to strip off the outer cell membrane. The cells were pelleted by centrifugation and resuspended in filtered sea water for $30 \mathrm{~min}$ at $8{ }^{\circ} \mathrm{C}$. Cell pellets were re-suspended and fixed with $2.5 \%$ glutaraldehyde prepared with $\mathrm{f} / 2$-Si medium for $3 \mathrm{~h}$ at $8{ }^{\circ} \mathrm{C}$. Cell pellets were washed twice 
with $\mathrm{f} / 2$-Si medium and fixed overnight at $8{ }^{\circ} \mathrm{C}$ with $2 \% \mathrm{OsO}_{4}$ made up with filtered sea water. The supernatant was removed and the cell pellet was allowed to adhere to a coverslip coated with poly-Llysine (molecular weight 70,000-150,000). The attached cells were washed for $10 \mathrm{~min}$ in a $1: 1$ solution of distilled water and filtered sea water, followed by a second wash in distilled water lasting $10 \mathrm{~min}$. The samples were then dehydrated in a series of ethanol $(10,30,50,70,90$ and $3 \times$ in $100 \%, 10$ min at each step), critical point dried (K850 Critical Point Dryer, Quorum/Emitech, West Sussex, UK), sputter-coated with gold, and examined with a Zeiss Sigma FE (Carl Zeiss Inc., Oberkochen, Germany) scanning electron microscope.

\subsection{PCR amplifications and sequencing}

The total algal DNA was extracted from $10 \mathrm{~mL}$ of exponentially growing Azadinium cultures using a plant DNA extraction kit (Sangon, Shanghai, China) according to the manufacturer's protocol. PCR amplifications were carried out using $1 \times$ PCR buffer, $50 \mu \mathrm{M}$ dNTP mixture, $0.2 \mu \mathrm{M}$ of each primer, $10 \mathrm{ng}$ of template genomic DNA, and $1 \mathrm{U}$ of ExTaq DNA Polymerase (Takara, Tokyo, Japan) in $50 \mu \mathrm{L}$ total volume reactions. The total ITS1-5.8S-ITS2 was amplified using ITSA and ITSB primers (Adachi et al., 1996). Approximately 1400 bp of the LSU rDNA (D1-D6) was amplified using the primers of D1R (Scholin et al., 1994) and 28-1483R (Daugbjerg et al., 2000). The PCR protocol was as follows: initial denaturation for $3.5 \mathrm{~min}$ at $94^{\circ} \mathrm{C}$, followed by 35 cycles of $50 \mathrm{~s}$ denaturation at $94{ }^{\circ} \mathrm{C}, 50 \mathrm{~s}$ annealing at $45^{\circ} \mathrm{C}$, and $80 \mathrm{~s}$ extension at $72{ }^{\circ} \mathrm{C}$, plus a final extension of $10 \mathrm{~min}$ at $72^{\circ} \mathrm{C}$. PCR products were sequenced directly in both directions using the ABI Big-Dye dyeterminator technique (Applied Biosystems, Foster City, CA, USA), according to the manufacturer's recommendations. New sequences were deposited in the GenBank with accession numbers KU686475 and KU686476.

\subsection{Sequence alignment and phylogenetic analysis}

Newly obtained LSU rDNA and ITS sequences of Azadinium poporum were aligned with the related sequences download from GenBank using the MAFFT v7.110 (Katoh et al., 2005) online program (http://mafft.cbrc.jp/alignment/server/). Alignments were manually checked with BioEdit v. 7.0.5 (Hall, 1999). The program Jmodeltest (Posada, 2008) was used to select the most appropriate model of molecular evolution with the Akaike information criterion (AIC). This test chose the TIM1 + I + G and TIM2 + G models for LSU and ITS, respectively. A Bayesian reconstruction of the data matrix was performed with MrBayes 3.1.2 (Ronquist and Huelsenbeck, 2003) using the best-fitting substitution model. Four Markov chain Monte Carlo (MCMC) chains ran for one million generations, with sampling every 1000 generations. A majority rule consensus tree was created to examine the posterior probabilities of each clade. The maximum-likelihood (ML) analyses were conducted using RaxML v7.2.6 (Stamatakis, 2006) on the T-REX web server (Boc et al., 2012) using the model GTR+G. Node support was assessed with 1000 bootstrap replicates.

\subsection{Chemical analysis of azaspiracids}

Cultures of Azadinium poporum were grown in $200 \mathrm{~mL}$ Erlenmeyer flasks under standard culture conditions to conduct an AZA analysis. About $10^{7}$ cells were collected by centrifugation at the exponential phase. Cell pellets were extracted with $300 \mu \mathrm{L}$ acetone by reciprocal shaking at $6.5 \mathrm{~m} \mathrm{~s}^{-1}$ with $0.9 \mathrm{~g}$ lysing matrix D (Thermo Savant, Illkirch, France) in a Bio101 FastPrep instrument (Thermo Savant, Illkirch, France) for $45 \mathrm{~s}$. The extracts were then centrifuged (Eppendorf 5415 R, Hamburg, Germany) at $16,100 \times \mathrm{g}$ at $4{ }^{\circ} \mathrm{C}$ for $15 \mathrm{~min}$. Each supernatant was transferred to a $0.45-\mu \mathrm{m}$ pore-size spin-filter (Millipore Ultrafree, Eschborn, Germany) and centrifuged for $30 \mathrm{~s}$ at $800 \times \mathrm{g}$, and the resulting filtrate was transferred into an LC autosampler vial for LC-MS/MS analysis.

\subsubsection{Single reaction monitoring (SRM) measurements}

Water was deionized and purified (Milli-Q, Millipore, Eschborn, Germany) to $18 \mathrm{M} \Omega \mathrm{cm}^{-1}$ or better quality. Formic acid (90\%, p.a.), acetic acid (p.a.) and ammonium formate (p.a.) were from Merck (Darmstadt, Germany). The solvents, methanol and acetonitrile, were high performance liquid chromatography (HPLC) grade (Merck, Darmstadt, Germany).

Mass spectral experiments were performed to survey for a wide array of AZAs. The analytical system consisted of an AB-SCIEX4000 Q Trap, triple quadrupole mass spectrometer equipped with a TurboSpray ${ }^{\circledR}$ interface coupled to an Agilent model 1100 LC. The LC equipment included a solvent reservoir, in-line degasser (G1379A), binary pump (G1311A), refrigerated autosampler (G1329A/G1330B), and temperature-controlled column oven (G1316A).

Separation of AZAs ( $5 \mu \mathrm{L}$ sample injection volume) was performed by reverse-phase chromatography on a $\mathrm{C} 8$ phase. The analytical column $(50 \mathrm{~mm} \times 2 \mathrm{~mm})$ was packed with $3 \mu \mathrm{m}$ Hypersil BDS $120 \AA$ (Phenomenex, Aschaffenburg, Germany) and maintained at $20^{\circ} \mathrm{C}$. The flow rate was $0.2 \mathrm{~mL} \mathrm{~min}^{-1}$ and gradient elution was performed with two eluants, wherein eluant $A$ was water and B was acetonitrile/water $(95: 5, \mathrm{v} / \mathrm{v})$, and both contained $2.0 \mathrm{mM}$ ammonium formate and $50 \mathrm{mM}$ formic acid. The initial conditions were 8 min column equilibration with $30 \%$ B, followed by a linear gradient to $100 \% \mathrm{~B}$ in $8 \mathrm{~min}$, isocratic elution until 18 min with $100 \% \mathrm{~B}$, and then returning to the initial conditions until $21 \mathrm{~min}$ (total run time: $29 \mathrm{~min}$ ).

The AZA profiles were determined in one period (0-18) min with curtain gas: 10 psi, CAD: medium, ion spray voltage: $5500 \mathrm{~V}$, ambient temperature; nebulizer gas at $10 \mathrm{psi}$, auxiliary gas was off, the interface heater was on, the declustering potential @ $100 \mathrm{~V}$, the entrance potential @ $10 \mathrm{~V}$, and the exit potential @ $30 \mathrm{~V}$. The SRM experiments were carried out in positive ion mode by selecting the transitions shown in Table 1. AZAs were calibrated against an external standard solution of AZA-2 (certified reference material (CRM) program of the IMB-NRC, Halifax, Canada) and expressed as AZA-2 equivalents.

Table 1

Mass transitions $m / z(\mathrm{Q} 1>\mathrm{Q} 3$ mass) and their respective AZAs.

\begin{tabular}{lll}
\hline Mass transition & Toxin & $\begin{array}{l}\text { Collision energy } \\
(\mathrm{CE})[\mathrm{V}]\end{array}$ \\
\hline $716>698$ & AZA-33 & 40 \\
$816>798$ & AZA-39 & 40 \\
$816>348$ & AZA-39 & 70 \\
$828>658$ & AZA-3 & 70 \\
$828>810$ & AZA-3 & 40 \\
$830>812$ & AZA-38 & 40 \\
$830>348$ & AZA-38 & 70 \\
$842>672$ & AZA-1 & 70 \\
$842>824$ & AZA-1, AZA-40 & 40 \\
$844>826$ & AZA-4, AZA-5 & 40 \\
$846>828$ & AZA-37 & 40 \\
$856>672$ & AZA-2 & 70 \\
$856>838$ & AZA-2 & 40 \\
$858>840$ & AZA-7, AZA-8, AZA-9, AZA-10, AZA-36 & 40 \\
$868>362$ & Undescribed & 70 \\
$870>852$ & Me-AZA-2 & 40 \\
$872>854$ & AZA-11, AZA-12 & 40 \\
$936>918$ & AZA-2 phosphate & 40 \\
\hline
\end{tabular}




\subsubsection{Precursor ion experiments}

Precursors of the fragments $m / z 348, m / z 360$ and $m / z 362$ were scanned in the positive ion mode from $\mathrm{m} / z 400$ to 950 under the following conditions: curtain gas at $10 \mathrm{psi}$, CAD at medium, ion spray voltage at $5500 \mathrm{~V}$, ambient temperature, a 10 psi nebulizer gas, the auxiliary gas was off, the interface heater was on, a declustering potential of $100 \mathrm{~V}$, a $10 \mathrm{~V}$ entrance potential, a $70 \mathrm{~V}$ collision energy, and a $12 \mathrm{~V}$ exit potential.

\subsubsection{Collision Induced Dissociation (CID) spectra}

CID spectra of $m / z 856$ and $m / z 936$ were recorded in the Enhanced Product Ion (EPI) mode in the mass range from $\mathrm{m} / \mathrm{z} 150$ to 960 in a positive ionization and unit resolution mode. The following parameters were applied: 10 psi curtain gas, medium $\mathrm{CAD}$, a $5500 \mathrm{~V}$ ion spray voltage, ambient temperature, a $10 \mathrm{psi}$ nebulizer gas, the auxiliary gas was off, the interface heater was on, there was a $100 \mathrm{~V}$ declustering potential, the collision energy spread was 0 and $10 \mathrm{~V}$, and the collision energy was $70 \mathrm{~V}$.

\section{Results}

\subsection{Morphology}

The cells of Azadinium poporum strain GM29 were 11.2$16.0 \mu \mathrm{m}$ long $($ mean $=13.3 \pm 1.2 \mu \mathrm{m}, n=30$ ) and $8.2-11.8 \mu \mathrm{m}$ wide (mean $=9.8 \pm 0.9 \mu \mathrm{m}, n=30$ ) with a median length: width ratio of around 1.4. The large nucleus was spherical to slightly elongated and located in the lower part of the cell (Fig. 1). Up to three pyrenoids were visible in the light microscope, and were located either in the epitheca or hypotheca (Fig. 1A). A single chloroplast was situated in the periphery of the cell (Fig. 1B).

The cells had a conical epitheca and a hemispherical hypotheca, interrupted by a deep and wide cingulum, descending less than half the cingulum width (Fig. 2A). Trichocysts were observed on the cell surface, including the cingular and sulcal plates. The cells showed a plate pattern of po, cp, x, 4', 3a, 6", 6C, 5S, 6"', $2^{\prime \prime \prime \prime}$. The cingulum was composed out of six plates of similar size (Fig. 2A and $B$ ). The rounded apical pore was located in the center of a pore plate (po) and covered by a cover plate (cp) (Fig. 2C). There was a distinct ventral pore (vp) located at the junction of the apical pore and the first two apical plates $\left(1^{\prime}, 2^{\prime}\right)$ (Fig. 2C). The first apical plate was not symmetrical (Fig. 2C). There were three anterior intercalary plates (1a, 2a and 3a) on the dorsal part of the epitheca. Plates 1a and 3a were pentagonal or hexagonal, much larger than the four-sided 2a (Fig. 2B and D). The first precingular plate was large and in contact with Plate 1a (Fig. 2D). The first antapical plate $\left(1^{\prime \prime \prime \prime}\right)$ was much smaller than the second antapical plate and displaced to the left (Fig. 2E). The sulcus was composed of an anterior sulcal plate (Sa), a median sulcal plate (Sm), a right sulcal plate (Sd), a left sulcal plate (Ss), and a posterior sulcal plate (Sp) (Fig. 2F). There was a distinct group of pores located on the dorsal side of the second antapical plate, where 10-23 pores were arranged in short rows (Fig. 2G). Cells with aberrant plate patterns (e.g., five apical plates, two anterior intercalary plate, five postcingular plates) were observed in the same culture (Fig. S1).

Supplementary Fig. S1 related to this article can be found, in the online version, at doi:10.1016/j.hal.2016.02.006.

\subsection{Molecular analysis and phylogeny}

For the LSU sequences, the similarity among the different ribotypes of Azadinium poporum ranged from $95.4 \%$ to $98.2 \%$ and the genetic distances ranged from 0.02 to 0.04 . In contrast, the similarity and genetic distances were around 93\% and 0.07 at interspecific level (Table 2). For the ITS sequences, the similarity among the different ribotypes of $A$. poporum ranged from $97.1 \%$ to $99.2 \%$, and the genetic distances ranged from 0.01 to 0.02 . In contrast, at the interspecific level, the similarity and genetic distances were around $91 \%$ and 0.08 (Table 3 ).

The ML and BI analysis that are based on LSU sequences generated similar phylogenetic trees (Fig. 3). Both Azadinium and $A$. poporum were monophyletic with maximal support (bootstrap $=100 \%$ in $\mathrm{ML}$ and $\mathrm{pp}=1.00$ in $\mathrm{BI}$, respectively). $A$. poporum comprised 3 well-supported clades, referred to as ribotype A, B, and $C$. The strain GM29 was a sister clade of ribotype $C$ with strong support (bootstrap $=100 \%$ in ML and pp $=0.99$ in BI, respectively).

The ML and BI analysis based on ITS sequences generated similar phylogenetic trees (Fig. 4). Azadinium poporum comprised three well-supported clades, referred to as ribotype A, B, and C. The strain GM29 was a sister clade of ribotype B with maximal support. GM29 belonged to neither ribotype B nor ribotype $C$ and was thus designated as a new ribotype, termed as ribotype $D$.

\subsection{AZA profile}

Precursor ion experiments of the typical AZA fragments $m / z$ $348, m / z 360$ and $m / z 362$ were performed to test the presence of AZAs. Whereas the $m / z 348$ and the $m / z 360$ experiments were negative, the $m / z 362$ experiment resulted in two peaks with $m / z$ 856 at a retention time of $12.4 \mathrm{~min}$ and $\mathrm{m} / z$ 936 at $11.5 \mathrm{~min}$. The CID spectra of both masses were recorded and resulted in identical spectra to those of AZA-2 and AZA-2 phosphate (Fig. 5). Quantification of both compounds against an external calibration solution of AZA-2 in the Selected Reaction Monitoring (SRM) mode gave an AZA-2 cell quota of $45 \pm 1 \mathrm{fg}$ cell $^{-1}$. AZA-2 phosphate was expressed as AZA-2 equivalent and determined as $0.7 \pm 0.5 \mathrm{fg} \mathrm{cell}^{-1}$.

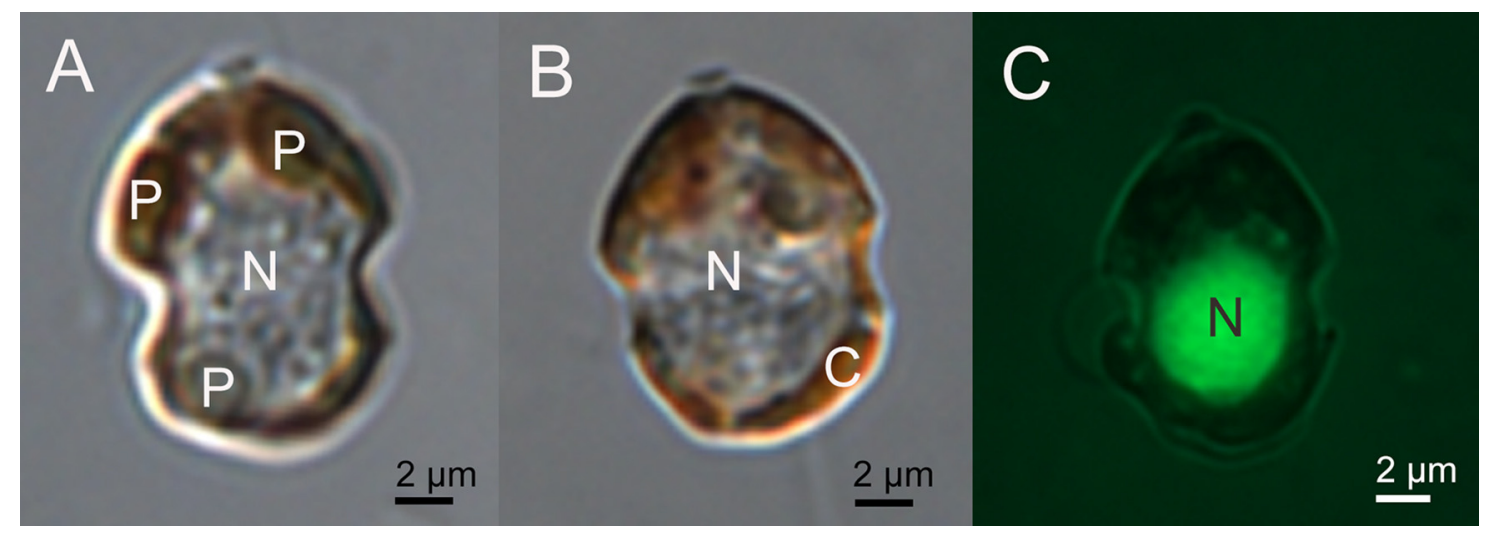

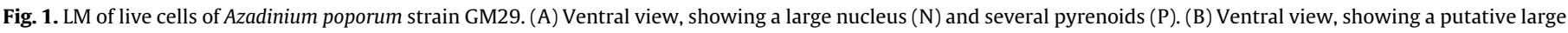
chloroplast. (C) Ventral view, showing a large nucleus (Sybr Green staining). 

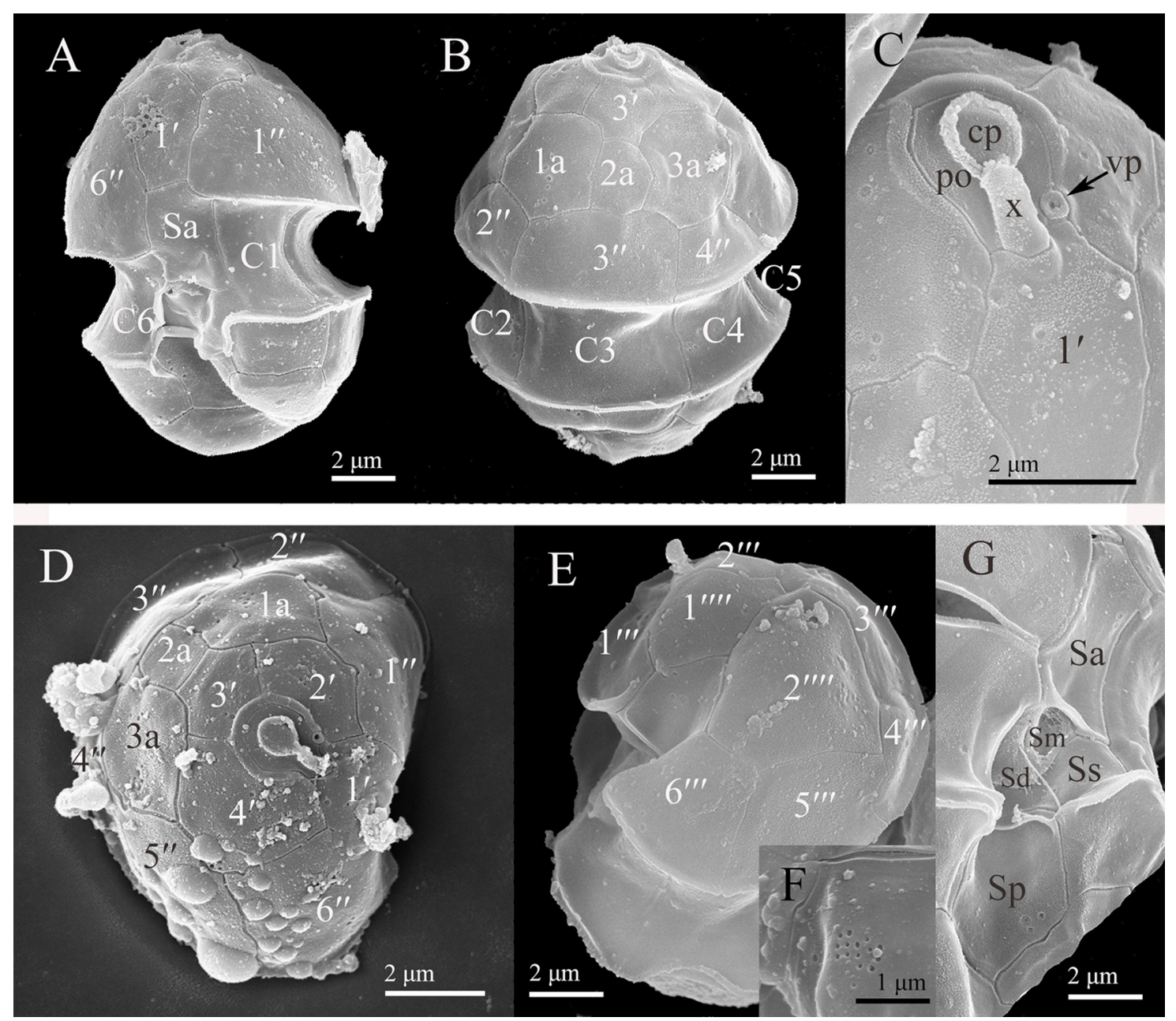

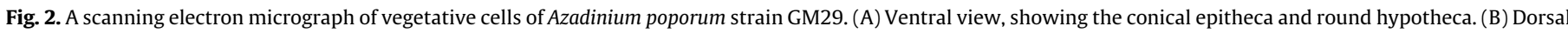

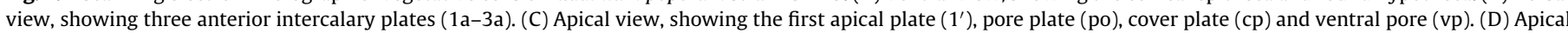

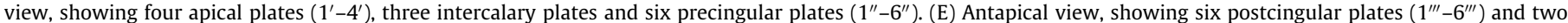

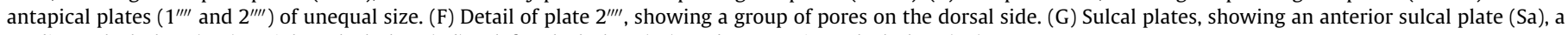
median sulcal plate (Sm), a right sulcal plate (Sd), a left sulcal plate (Ss), and a posterior sulcal plate (Sp).

Table 2

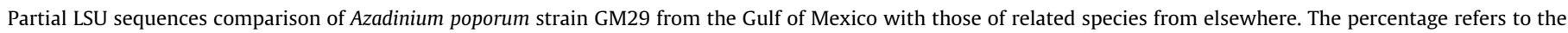
similarity out of partial LSU sequences (701 bp); the numeral in brackets refers to pairwise genetic distance.

\begin{tabular}{|c|c|c|c|c|c|c|}
\hline & GM29 & G25 & G66 & G42 & UTHC5 & AZCHO2 \\
\hline GM29 (ribotype D) & - & & & & & \\
\hline G25 (ribotype B) & $97.7 \%(0.02)$ & - & & & & \\
\hline G66 (ribotype B) & $97.8 \%(0.02)$ & $98.2 \%(0.02)$ & - & & & \\
\hline G42 (ribotype C) & $98.2 \%(0.02)$ & $97.7 \%(0.02)$ & $97.5 \%(0.02)$ & - & & \\
\hline UTHC5 (ribotype A) & $95.4 \%(0.04)$ & $96.2 \%(0.04)$ & $96.4 \%(0.03)$ & $96.5 \%(0.03)$ & - & \\
\hline AZCH02 (A. dalianense) & $92.7 \%(0.07)$ & $91.7 \%(0.08)$ & $92.2 \%(0.07)$ & $93.2 \%(0.06)$ & $92.7 \%(0.06)$ & - \\
\hline
\end{tabular}

Table 3

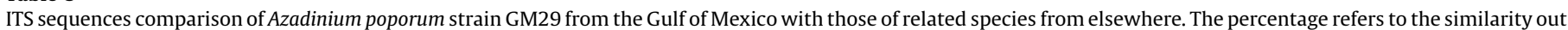
of ITS region sequences; the numeral in bracket refers to pairwise genetic distance.

\begin{tabular}{|c|c|c|c|c|c|c|}
\hline & GM29 & G25 & G66 & G42 & UTHC5 & AZCH02 \\
\hline GM29 (ribotype D) & - & & & & & \\
\hline G25 (ribotype B) & $98.8 \%(0.01)$ & - & & & & \\
\hline G66 (ribotype B) & $98.7 \%(0.01)$ & $99.2 \%(0.01)$ & - & & & \\
\hline G42 (ribotype C) & $98.4 \%(0.02)$ & $98.2 \%(0.02)$ & $97.7 \%(0.02)$ & - & & \\
\hline UTHC5 (ribotype A) & $97.6 \%(0.02)$ & $97.3 \%(0.02)$ & $97.1 \%(0.02)$ & $97.3 \%(0.02)$ & - & \\
\hline AZCH02 (A. dalianense) & $90.8 \%(0.08)$ & $90.6 \%(0.08)$ & $90.8 \%(0.08)$ & $90.6 \%(0.08)$ & $91.3 \%(0.08)$ & - \\
\hline
\end{tabular}




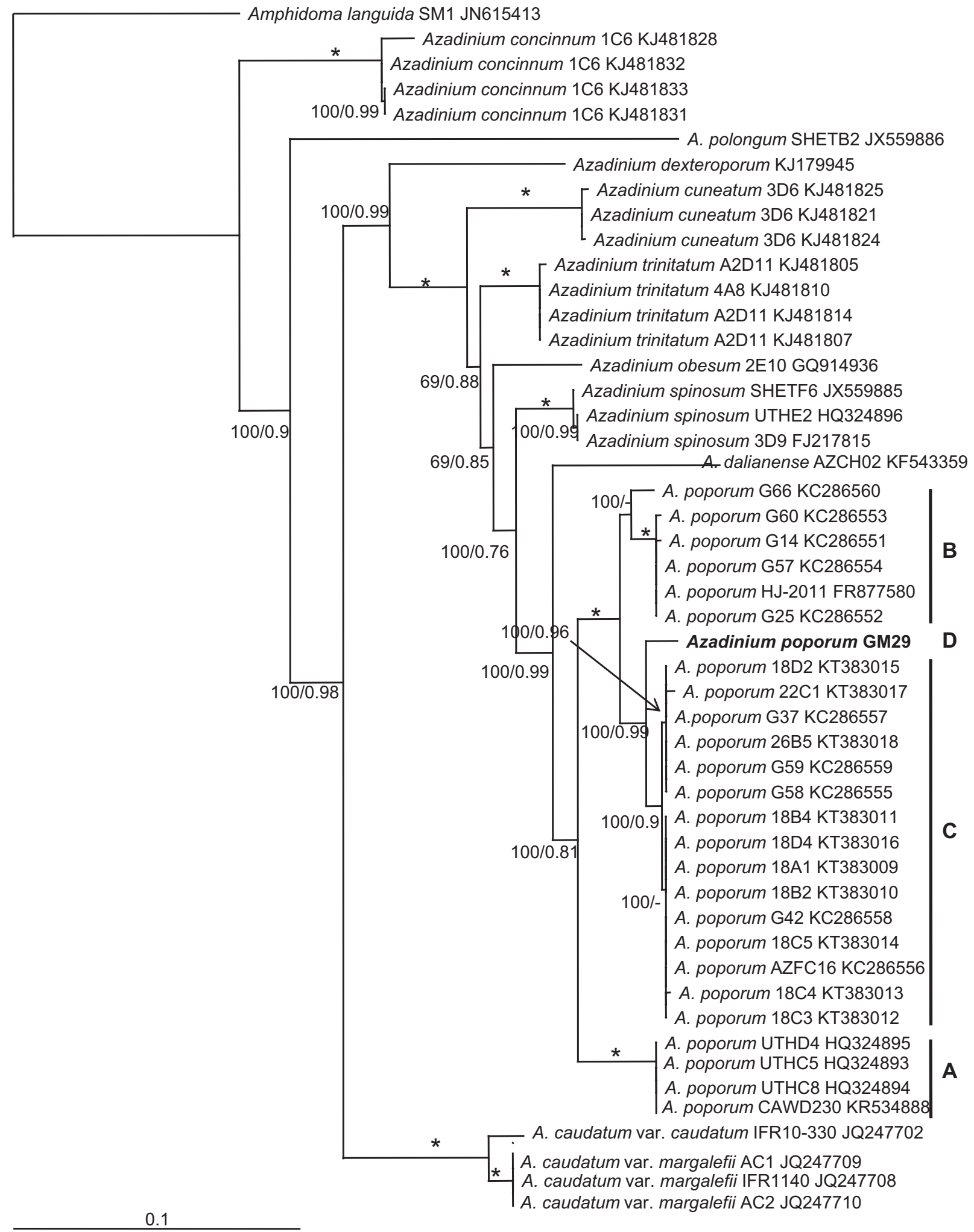

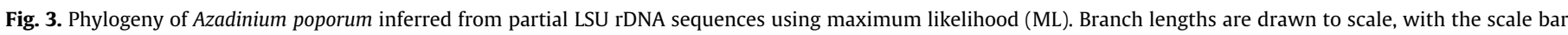

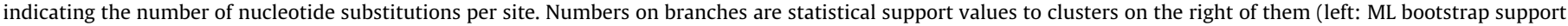
values; right: Bayesian posterior probabilities).

\section{Discussion}

\subsection{Morphology and biogeography}

This is the first report of the toxic genus Azadinium in waters of the United States. In contrast to the high diversity of Azadinium in
Europe (up to 9 species) (Tillmann et al., 2009, 2014), there are only a few species recovered in Asian waters (A. poporum, A. dalianense) (Gu et al., 2013; Luo et al., 2013), Argentinean waters ( $A$. cf. spinosum, A. poporum (Akselman and Negri, 2012; Tillmann et al., 2016), the Mexican Pacific (A. spinosum) (Hernández-Becerril et al., 2012), and New Zealand waters (A. poporum) (Smith et al., 2015), 


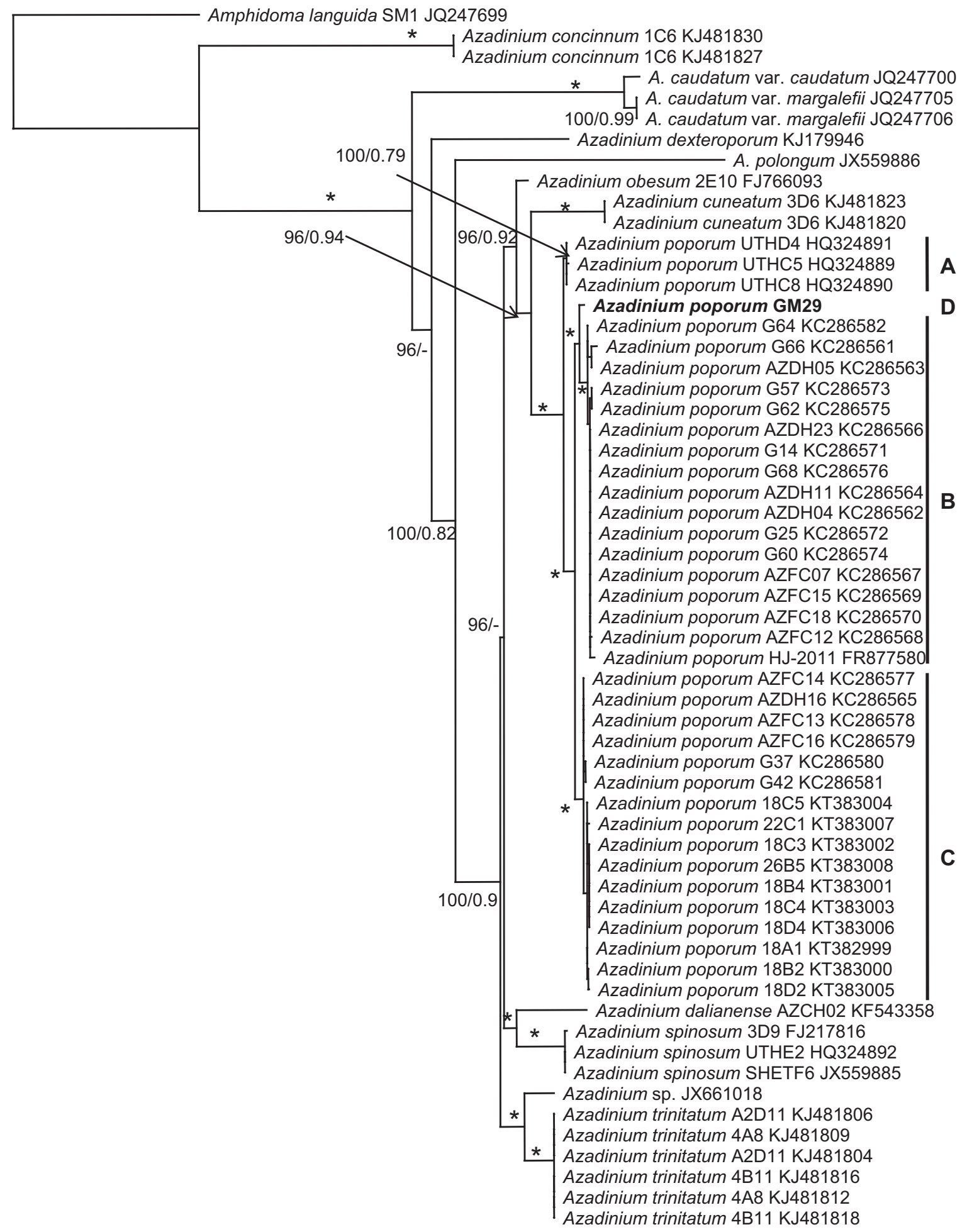

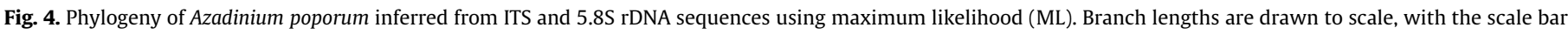

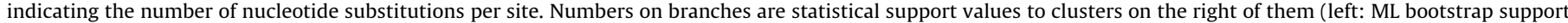
values; right: Bayesian posterior probabilities).

probably because they are small and are not included in most routine monitoring. A. poporum seems to be the most widely distributed species with reports from the northeast Atlantic (Tillmann et al., 2010), the northwest Pacific (Potvin et al., 2011; Gu et al., 2013), southwest Atlantic (Argentina, Tillmann et al., 2016) and southwest Pacific (New Zealand, Smith et al.,
2015). These species require more attention because of their toxicity, which causes azaspiracid shellfish poisoning (AZP). This occurred through consumption of AZA contaminated mussels that were cultured in Ireland and consumed in several other countries (Satake et al., 1998; Twiner et al., 2008; Klontz et al., 2009). But, as in many countries, the mouse bioassay is still used for seafood 

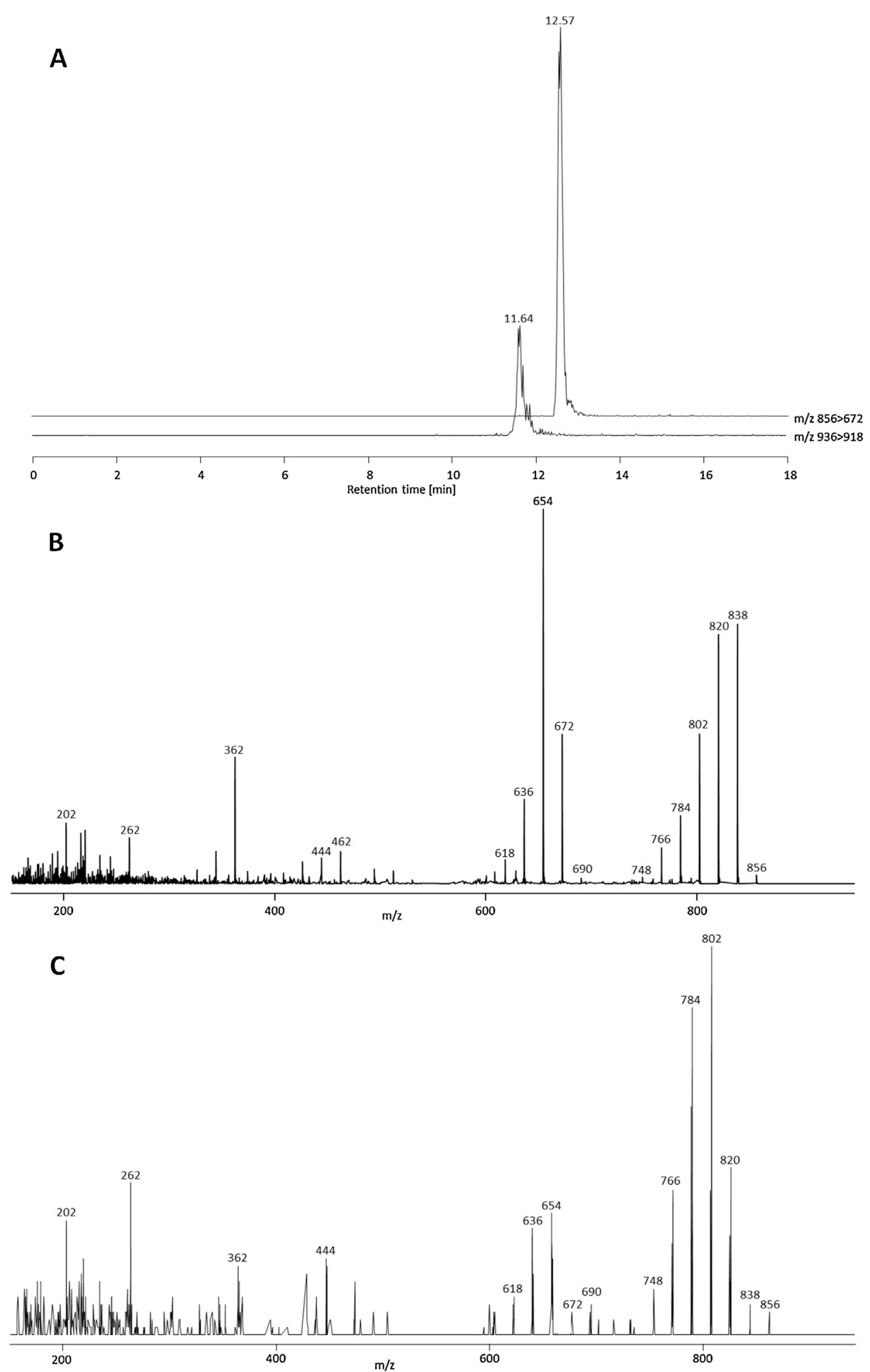

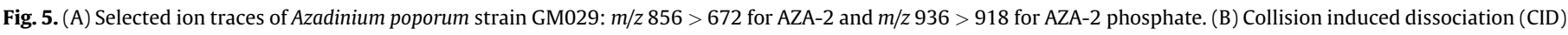
spectrum of $m / z 856$ (AZA-2). (C) CID spectrum of $m / z 936$ (AZA-2 phosphate).

control, and azaspiracid shellfish poisoning may have been misidentified as diarrhetic shellfish poisoning (DSP) because the symptoms of both poisonings in mice are the same. Only mass spectral analysis of contaminated shellfish can discriminate between AZP and DSP events. Therefore, insufficient attention has been paid to this group of dinoflagellates in other areas and higher diversities can be expected to be found in the near future.
The key morphological characters of the genus Azadinium include the presence/absence of an antapical spine, the arrangement of the first precingular plate (whether in contact with the first anterior intercalary plate or not), and the location of the ventral pore (Tillmann et al., 2014). The distinct position of the ventral pore located at the junction of the pore plate and the first two apical plates is characteristic of Azadinium poporum 
(Tillmann et al., 2011), but such a kind of ventral pore was also observed in Azadinium dalianense and Azadinium trinitatum (Luo et al., 2013; Tillmann et al., 2014). A. dalianense has only three apical plates and two anterior intercalary plates (Luo et al., 2013), whereas A. trinitatum shares an identical plate pattern with that of A. poporum (Tillmann et al., 2014). However, A. trinitatum has an antapical spine and the left side of the suture po/ $1^{\prime}$ is farther away from the apical pore than A. poporum. Based on the location of the ventral pore and the absence of an antapical spine and configuration of Plate $1^{\prime \prime}$, the strain GM29 can be safely classified as $A$. poporum. A group of pores on the dorsal side of the second antapical plate was observed in the Gulf of Mexico strain, which was likewise present in a Korea strain (ribotype B) (Potvin et al., 2011), and many Argentinean and Chinese strains (ribotype C) (Tillmann et al., 2016; Gu personal observations), suggesting that this is a common feature of $A$. poporum although it was not mentioned in the original description. The strain GM29 was obtained by incubating surface sediments from the Gulf of Mexico directly, supporting the idea that $A$. poporum has a cyst stage ( $\mathrm{Gu}$ et al., 2013), although there was no direct observation of such a cyst. The cysts might be too small, too inconspicuous and rare, thus escaping microscopic detection during routine plankton surveys and cyst studies so far. In line with previously observations ( $\mathrm{Gu}$ et al., 2013; Tillmann et al., 2011), the Gulf of Mexico strain A. poporum cells also sometimes show aberrant plate patterns in culture.

Before this study, Azadinium poporum was reported in the North Sea (ribotype A), Yellow Sea, East China Sea, South China Sea (ribotype B, C), New Zealand (ribotype A) and Argentina (ribotype C) (Tillmann et al., 2011, 2016; Gu et al., 2013; Smith et al., 2015). The distribution of $A$. poporum is extended to the Gulf of Mexico, suggesting that this is a widespread species. A. poporum of various ribotypes share identical thecate morphology, are relevant to toxicity, and thus highlight the necessity to develop molecularbased assays for targeting all ribotypes.

\subsection{Phylogeny and genetic differentiation}

The results support the monophyly of the genus Azadinium and A. poporum (Gu et al., 2013; Tillmann et al., 2014). However, the phylogenetic position of $A$. poporum strain GM29 is not consistent, and forms a sister clade either to ribotype $\mathrm{B}$ (LSU) or ribotype $\mathrm{C}$ (ITS), whereas phylogenetic positions of other strains of $A$. poporum are consistent. Thus GM29 was recognized as a new ribotype. More ribotypes can be expected as still limited sequences from a few geographical areas are available for this species. Unlike other dinoflagellates, the genetic distances of LSU rDNA among $A$. poporum ribotypes are greater than those of ITS sequences (Tables 2 and 3), supporting the idea that LSU is a better fragment for molecular discrimination (Toebe et al., 2013). However, whether the primers and probes for European $A$. poporum are also applicable for other ribotypes remains to be confirmed.

\subsection{Toxin profiles}

AZAs have been reported in shellfish of Pacific USA origin, but no details were provided (Trainer et al., 2013). AZA-2 was found in three plankton samples collected in Washington State (northeast Pacific), although neither AZA-1 nor AZA-3 were detected there (Trainer et al., 2013). AZA-1 was the dominant toxin profile in plankton samples collected in the North Sea (Krock et al., 2009), which was later ascribed to Azadinium spinosum (Tillmann et al., 2009). For all available $A$. spinosum strains, AZA-2 is present only in conjunction with AZA-1 (Tillmann et al., 2009, 2012b). For the potential toxic Azadinium dexteroporum, abundance of azaspiracid is very low and neither AZA-1 nor AZA-2 were produced (Percopo et al., 2013). A. poporum is the only known Azadinium species producing exclusively or predominantly AZA-2 (Krock et al., 2014; Tillmann et al., 2016; present study), thus it is likely responsible for the toxin from the plankton sample collected in Washington State (Trainer et al., 2013). AZAs were also present in shellfish from eastern Canada (Twiner et al., 2008), suggesting that toxic species (e.g., A. poporum, A. spinosum) might be present there too. In addition, the toxin profile of the A. poporum isolate from the Gulf of Mexico is identical with the profile of $A$. poporum from Argentinean shelf waters including the recently discovered AZA-2 phosphate (Tillmann et al., 2016), even though both isolates belong to different ribotypes: C (Argentinean isolate) and D (Gulf of Mexico isolate). In contrast, only AZA-1 was detected in mussels collected from Baja California, Mexico (García-Mendoza et al., 2014), consistent with the fact that $A$. spinosum is present in the Mexican Pacific (Hernández-Becerril et al., 2012). Interestingly, shellfish samples from Morocco (Taleb et al., 2006) and Portugal (Vale et al., 2008) show an AZA-profile with predominant AZA-2, followed by AZA-1, quite different from any shellfish sample from Ireland, Norway, Spain or France (Twiner et al., 2008). Identification of genes involved in saxitoxin biosynthesis contributed to a rapid and accurate molecular method to quantify toxic Alexandrium species from marine waters (Murray et al., 2011). However, AZA-related genes have not been identified yet, and their knowledge will contribute to a promising approach for monitoring and studying toxic Azadinium in future studies.

\section{Conclusions}

The first record of Azadinium poporum in the Gulf of Mexico supports a wide distribution of this species. Further efforts are needed to examine if it is also present in the Atlantic coast of the USA and Canada. A. poporum in the Gulf of Mexico is genetically different from strains from elsewhere, and thus represents a new ribotype. This strain, however, produces predominantly AZA-2 and AZA-2 phosphate, identical to the profiles produced by the Argentinean strains (Tillmann et al., 2016).

\section{Acknowledgements}

We thank Urban Tillmann and an anonymous reviewer for constructive suggestions that improved the ms. Haifeng $\mathrm{Gu}$ was supported by the National Natural Science Foundation of China (41376170, 41306171) and the Public Science and Technology Research Funds Projects of Ocean (201305027). Kenneth Neil Mertens was a postdoctoral fellow of FWO Belgium. Andrea M. Price was supported by a Natural Science and Engineering Research Council of Canada (NSERC) doctoral scholarship (CGSD3). Sample collection was supported by the National Oceanic and Atmospheric Administration, Center for Sponsored Coastal Ocean Research, under award NA09NOS4780204 to Louisiana Universities Marine Consortium and award NA09NOS4780230 to Louisiana State University.[SS]

\section{References}

Adachi, M., Sako, Y., Ishida, Y., 1996. Analysis of Alexandrium (Dinophyceae) species using sequences of the $5.8 \mathrm{~S}$ ribosomal DNA and internal transcribed spacer regions. J. Phycol. 32 (3), 424-432.

Akselman, R., Negri, R.M., 2012. Blooms of Azadinium cf. spinosum Elbrächter et Tillmann (Dinophyceae) in northern shelf waters of Argentina, Southwestern Atlantic. Harmful Algae 19, 30-38

Boc, A., Diallo, A.B., Makarenkov, V., 2012. T-REX: a web server for inferring, validating and visualizing phylogenetic trees and networks. Nucleic Acids Res. 40 (W1), W573-W579.

Daugbjerg, N., Hansen, G., Larsen, J., Moestrup, Ø., 2000. Phylogeny of some of the major genera of dinoflagellates based on ultrastructure and partial LSU rDNA sequence data, including the erection of three new genera of unarmoured dinoflagellates. Phycologia 39 (4), 302-317. 
García-Mendoza, E., Sánchez-Bravo, Y.A., Turner, A., Blanco, J., O’Neil, A., ManceraFlores, J., Pérez-Brunius, P., Rivas, D., Almazán-Becerril, A., Peña-Manjarrez, J.L., 2014. Lipophilic toxins in cultivated mussels (Mytilus galloprovincialis) from Baja California, Mexico. Toxicon 90, 111-123.

Gu, H., Luo, Z., Krock, B., Witt, M., Tillmann, U., 2013. Morphology, phylogeny and azaspiracid profile of Azadinium poporum (Dinophyceae) from the China Sea. Harmful Algae 21-22, 64-75.

Guillard, R.R.L., Ryther, J.H., 1962. Studies of marine planktonic diatoms. I. Cyclotella nana Hustedt and Detonula confervacea Cleve. Can. J. Microbiol. 8 (2), 229-239.

Hall, T.A., 1999. BioEdit: a user-friendly biological sequence alignment editor and analysis program for Windows 95/98/NT. Nucleic Acids Symp. Ser. 41, 95-98.

Hernández-Becerril, D.U., Barón-Campis, S.A., Escobar-Morales, S., 2012. A new record of Azadinium spinosum (Dinoflagellata) from the tropical Mexican Pacific. Rev. Biol. Mar. Oceanogr. 47 (3), 553-557.

Katoh, K., Kuma, K., Toh, H., Miyata, T., 2005. MAFFT version 5: improvement in accuracy of multiple sequence alignment. Nucleic Acids Res. 33 (2), 511-518.

Klontz, K.C., Abraham, A., Plakas, S.M., Dickey, R.W., 2009. Mussel-associated azaspiracid intoxication in the United States. Ann. Intern. Med. 150 (5), 361.

Krock, B., Tillmann, U., John, U., Cembella, A.D., 2009. Characterization of azaspiracids in plankton size-fractions and isolation of an azaspiracid-producing dinoflagellate from the North Sea. Harmful Algae 8 (2), 254-263.

Krock, B., Tillmann, U., Witt, M., Gu, H., 2014. Azaspiracid variability of Azadinium poporum (Dinophyceae) from the China Sea. Harmful Algae 36, 22-28.

Lopez-Rivera, A., O'Callaghan, K., Moriarty, M., O’Driscoll, D., Hamilton, B., Lehane M., James, K., Furey, A., 2010. First evidence of azaspiracids (AZAs): a family of lipophilic polyether marine toxins in scallops (Argopecten purpuratus) and mussels (Mytilus chilensis) collected in two regions of Chile. Toxicon 55 (4) $692-701$.

Luo, Z., Gu, H., Krock, B., Tillmann, U., 2013. Azadinium dalianense, a new dinoflagellate species from the Yellow Sea, China. Phycologia 52 (6), 625-636.

Murray, S.A., Wiese, M., Stüken, A., Brett, S., Kellmann, R., Hallegraeff, G., Neilan, B.A. 2011. sxtA-based quantitative molecular assay to identify saxitoxin-producing harmful algal blooms in marine waters. Appl. Environ. Microbiol. 77 (19), 7050-7057.

Nézan, E., Tillmann, U., Bilien, G., Boulben, S., Chèze, K., Zentz, F., Salas, R., Chomérat, N., 2012. Taxonomic revision of the dinoflagellate Amphidoma caudata: transfer to the genus Azadinium (Dinophyceae) and proposal of two varieties, based on morphological and molecular phylogenetic analyses. J. Phycol. 48 (4), 925-939.

Percopo, I., Siano, R., Rossi, R., Soprano, V., Sarno, D., Zingone, A., 2013. A new potentially toxic Azadinium species (Dinophyceae) from the Mediterranean Sea, A. dexteroporum sp. nov. J. Phycol. 49 (5), 950-966.

Posada, D., 2008. jModelTest: phylogenetic model averaging. Mol. Biol. Evol. 25 (7), 1253-1256.

Potvin, É., Jeong, H.J., Kang, N.S., Tillmann, U., Krock, B., 2011. First report of the photosynthetic dinoflagellate genus Azadinium in the Pacific Ocean: morphology and molecular characterization of Azadinium cf. poporum. J. Eukaryot. Microbiol. 59 (2), 145-156.

Ronquist, F., Huelsenbeck, J.P., 2003. MrBayes 3: Bayesian phylogenetic inference under mixed models. Bioinformatics 19 (12), 1572-1574.

Satake, M., Ofuji, K., Naoki, H., James, K.J., Furey, A., McMahon, T., Silke, J., Yasumoto, T. 1998. Azaspiracid, a new marine toxin having unique spiro ring assemblies, isolated from Irish mussels, Mytilus edulis. J. Am. Chem. Soc. 120 (38), 9967-9968.
Scholin, C.A., Herzog, M., Sogin, M., Anderson, D.M., 1994. Identification of groupand strain-specific genetic markers for globally distributed Alexandrium (Dinophyceae). II. Sequence analysis of a fragment of the LSU rRNA gene. J. Phycol. 30 (6), 999-1011

Smith, K.F., Rhodes, L., Harwood, D.T., Adamson, J., Moisan, C., Munday, R., Tillmann, U., 2015. Detection of Azadinium poporum in New Zealand: the use of molecular tools to assist with species isolations. J. Appl. Phycol., http://dx.doi.org/10.1007/ s10811-015-0667-5.

Stamatakis, A., 2006. RAxML-VI-HPC: maximum likelihood-based phylogenetic analyses with thousands of taxa and mixed models. Bioinformatics 22 (21), 2688-2690.

Taleb, H., Vale, P., Amanhir, R., Benhadouch, A., Sagou, R., Chafik, A., 2006. First detection of azaspiracids in mussels in north west Africa. J. Shellfish Res. 25 (3), 1067-1070.

Tillmann, U., Elbrächter, M., Krock, B., John, U., Cembella, A., 2009. Azadinium spinosum gen. et sp. nov. (Dinophyceae) identified as a primary producer of azaspiracid toxins. Eur. J. Phycol. 44 (1), 63-79.

Tillmann, U., Elbrächter, M., John, U., Krock, B., Cembella, A., 2010. Azadinium obesum (Dinophyceae), a new nontoxic species in the genus that can produce azaspiracid toxins. Phycologia 49 (2), 169-182.

Tillmann, U., Elbrächter, M., John, U., Krock, B., 2011. A new non-toxic species in the dinoflagellate genus Azadinium: A. poporum sp. nov. Eur. J. Phycol. 46 (1), 74-87.

Tillmann, U., Salas, R., Gottschling, M., Krock, B., O’Driscoll, D., Elbrächter, M., 2012a. Amphidoma languida sp. nov. (Dinophyceae) reveals a close relationship between Amphidoma and Azadinium. Protist 163 (5), 701-719.

Tillmann, U., Soehner, S., Nézan, E., Krock, B., 2012b. First record of the genus Azadinium (Dinophyceae) from the Shetland Islands, including the description of Azadinium polongum sp. nov. Harmful Algae 20, 142-155.

Tillmann, U., Gottschling, M., Nézan, E., Krock, B., Bilien, G., 2014. Morphological and molecular characterization of three new Azadinium species (Amphidomataceae, Dinophyceae) from the Irminger Sea. Protist 165 (4), 417-444.

Tillmann, U., Borel, C.M., Barrera, F., Lara, R., Krock, B., Almandoz, G.O., Witt, M., Trefault, N., 2016. Azadinium poporum from the Argentine continental shelf, southwestern Atlantic, produces azaspiracid-2 and azaspiracid-2 phosphate. Harmful Algae 51, 40-55.

Toebe, K., Joshi, A.R., Messtorff, P., Tillmann, U., Cembella, A., John, U., 2013. Molecular discrimination of taxa within the dinoflagellate genus Azadinium, the source of azaspiracid toxins. J. Plankton Res. 35 (1), 225-230.

Trainer, V.L., Moore, L., Bill, B.D., Adams, N.G., Harrington, N., Borchert, J., Da Silva, D.A., Eberhart, B.T.L., 2013. Diarrhetic shellfish toxins and other lipophilic toxins of human health concern in Washington State. Mar. Drugs 11 (6), 1815-1835.

Twiner, M.J., Rehmann, N., Hess, P., Doucette, G.J., 2008. Azaspiracid shellfish poisoning: a review on the chemistry, ecology, and toxicology with an emphasis on human health impacts. Mar. Drugs 6 (2), 39-72.

Ueoka, R., Ito, A., Izumikawa, M., Maeda, S., Takagi, M., Shin-ya, K., Yoshida, M., van Soest, R.W.M., Matsunaga, S., 2009. Isolation of azaspiracid-2 from a marine sponge Echinoclathria sp. as a potent cytotoxin. Toxicon 53 (6), 680-684.

Vale, P., Bire, R., Hess, P., 2008. Confirmation by LC-MS/MS of azaspiracids in shellfish from the Portuguese north-western coast. Toxicon 51 (8), 1449-1456.

Yao, J., Tan, Z., Zhou, D., Guo, M., Xing, L., Yang, S., 2010. Determination of azaspiracid-1 in shellfishes by liquid chromatography with tandem mass spectrometry. Chin. J. Chromatogr. 28 (4), 363-367 (in Chinese). 